\title{
Implementasi Hidden Curriculum Melalui Ekstrakurikuler Keagamaan: Studi Kasus
}

\author{
Achmad Syarifudin ${ }^{1 *}$, Dede Sutisna $^{2}$, Ani Cahyadi $^{3}$, Padjrin $^{1}$, Cholidi $^{1}$ \\ ${ }^{1}$ UIN Raden Fatah Palembang, Indonesia \\ ${ }^{2}$ UIN Sunan Gunung Djati Bandung, Indonesia \\ ${ }^{3}$ Universitas Islam Negeri Antasari Banjarmasin, Indonesia
}

\begin{abstract}
Abstrak: Penelitian ini bertujuan untuk mengetahui program pembinaan keberagamaan siswa melalui kegiatan ekstrakurikuler dan implementasi hidden curriculum di Madrasah Aliyah Patra Mandiri Palembang. Penelitian ini merupakan penelitian kualitatif dengan pendekatan deskritif analitis, maka dalam pengumpulan data menggunakan teknik observasi, wawancara mendalam, dokumentasi dan analisis datanya menggunakan analisis data model Milles dan Huberman, yaitu melalui proses reduksi, display dan verifikasi. Penelitian ini menyimpulkan bahwa implementasi hidden curriculum dalam ekstrakurikuler keagamaan melalui tiga cara yaitu 1) kegiatan rutin yaitu doa bersama, salat zuhur berjamaah, salat Duha, salaman pagi, dan silaturahmi siswa dengan guru; 2) kegiatan mingguan yaitu Tahsinul Qur'an, Marhaba, Barzanji, Muhadhoroh, dan salat Jumat; dan 3) keteladanan guru yaitu kedisplinan, silaturahmi dewan guru, berpakaian rapi dan sopan, dan hidup Bersih.
\end{abstract}

Kata Kunci: hidden curriculum, keberagamaan, ekstrakurikuler keagamaan

\begin{abstract}
This study aims to determine the student's religious development program through extracurricular activities and implementation of hidden curriculum at Madrasah Aliyah Patra Mandiri Palembang. This research is a qualitative research with analytical descriptive approach, then in collecting data using observation techniques, in-depth interviews, documentation and data analysis using data analysis model Milles and Huberman, namely through the process of reduction, display and verification. This study concludes that the implementation of the hidden curriculum in religious extracurricular activities is carried out in three ways, namely 1) routine activities, namely group prayer, congregational zuhur prayer, Duha prayer, morning greetings, and student-teacher friendship; 2) weekly activities, namely Tahsinul Qur'an, Marhaba, Barzanji, Muhadhoroh, and Friday prayers; and 3) exemplary teachers, namely discipline, teacher council relations, neatly and politely dressed, and clean living.
\end{abstract}

Keywords: hidden curriculum, religiosity, religious extracurricular

\section{Pendahuluan}

Pendidikan menjadi sorotan utama dalam penyelesaian masalah remaja yang terjadi, hal ini sesuai dengan arti pendidikan dalam Pasal 1 Ayat 1
Undang- undang Republik Indonesia Nomor 20 Tahun 2003 tentang Sistem Pendidikan Nasional, yang berbunyi: "Pendidikan adalah usaha sadar dan terencana untuk mewujudkan suasana belajar dan proses pembelajaran agar peserta didik secara aktif

\footnotetext{
* Corresponding Author: Achmad Syarifudin (achmadsyarifudin73@radenfatah.ac.id). UIN Raden Fatah Palembang, Indonesia
} 
mengembangkan potensi dirinya untuk memiliki kekuatan spiritual keagamaan, pengendalian diri, kepribadian, kecerdasan, akhlak mulia, serta keterampilan yang diperlukan dirinya, masyarakat, bangsa dan negara." (Penyusun, 2003).

Dari pengertian pendidikan tersebut sudah sangat jelas bahwa pendidikan seharusnya mampu membawa perubahan bagi pesera didik baik dalam keagamaan, kecerdasan hidup bersosial bahkan kecerdasan intelektual. Namun kenyataannya, pendidikan di sekolah saja tidak membuat remaja sebagai peserta didik menyadari esensi dari pendidikan yang ditempuh selama ini.

Namun demikian, ketidaksesuaian antara teori dan kenyataan ini membuat resah masyarakat. Pendidikan yang seharusnya dapat dijadikan dasar berperilaku sesuai dengan norma yang ada di masyarakat hanya sebatas teori tanpa praktik yang nyata. Selain itu, kebanyakan dari remaja melaksanakan pendidikan hanya sebatas pergi ke sekolah dan kemudian pulang ke rumah saja, sedangkan dalam praktik kehidupan sehari-hari tidak sejalan dengan ilmu yang diperoleh di sekolah. Sehingga banyak remaja yang berprilaku tidak sesuai dengan nilai dan norma agama serta norma hukum yang berlaku. Pendidikan dari orang tua yang tidak mencerminkan sikap-sikap keagamaan dapat menjadikan anak bersikap sesuai dengan pendidikan atau sikap yang dicontohkan oleh orang tuanya tersebut.

Generasi muda di Indonesia khususnya para pelajar dari berbagai jenjang saat ini dalam kondisi yang sangat memprihatinkan di bidang moralitas. Padahal, mereka dianggap sebagai aset penting bangsa yang akan menentukan masa depan bangsa. Banyak kasus yang merusak moral pelajar terjadi saat ini yaitu narkoba, seks bebas, minuman keras, hamil di luar nikah, tawuran, dan lain sebagainya. Sebagaimana survey terbaru pada Bulan Februari
2017 oleh BNN mengungkapkan pada tahun 2014, $22 \%$ pelajar dan mahasiswa sebagai pengguna narkoba. Pada tahun 2016, 2 dari 100 pelajar/mahasiswa sebagai pengguna narkoba. 1 dari orang pelajar/mahasiswa pernah minum alkohol di tahun 2016. Kemudian seks pra-nikah, di tahun 2016 diperkirakan ada 1 dari 20 orang pelajar/mahasiswa yang pernah melakukan hubungan seks pra-nikah (BNN, 2016). Apa yang dilakukan para pelajar sungguh jauh mencerminkan nilai-nilai agama dan masyarakat. Perbuatan tersebut dilakukan kurangnya pembinaan keberagamaan dari keluarga, sekolah, dan masyarakat.

Berbagai problema para pelajar di bidang moralitas tersebut tidak dapat terpecahkan melainkan dengan cara kembali kepada ajaran agama yang salah satu caranya dengan mengefektikan pendidikan agama di sekolah. Sebagaimana Malik Fajar (2005) menjelaskan sekolah sebagai lembaga pendidikan yang terencana masih menjadi tumpuan utama untuk membentuk watak dan moralitas anak bangsa. Di samping itu, dituntut peran dari keluarga dan masyarakat.

Muhaimin (2009) menjelaskan mengefektikan pendidikan agama di sekolah haruslah mencakup tiga aspek secara terpadu, yaitu: (1) knowing, yakni agar peserta didik dapat mengetahui dan memahami ajaran dan nilai-nilai agama; (2) doing, yakni agar peserta didik dapat mempraktikkan ajaran dan nilai-nilai agama, dan (3) being, yakni agar peserta didik dapat menjalani hidupnya sesuai dengan nilai-nilai dan ajaran agama. Ketiga aspek tersebut haruslah dilakukan secara terpadu dalam membina keberagamaan siswa di madrasah. Tidak hanya tiga aspek tersebut, melainkan diperlukan dukungan dari berbagai pihak di madrasah seperti kepala madrasah, dewan guru, tata usaha, dan masyarakat sekitar. 
Pembentukan moralitas siswa di madrasah tidak hanya dengan cara mengefektikan pendidikan agama melainkan dengan cara mengembangkan budaya agama/ekstrakurikuler. Hal ini sebagai upaya untuk menanamkan nilai-nilai agama kepada siswa dengan tujuan memperkokoh keimanan serta menjadi pribadi yang memiliki kesadaran beragama dan berakhlak mulia. Kegiatan ini sangat penting karena merupakan rangkaian kegiatan yang mendukung tujuan pendidikan nasional. Sebagaimana Muhaimin menjelaskan bahwa pengembangan budaya agama di lingkungan sekolah mempunyai landasan yang kokoh baik secara normatif religius maupun secara konstitusional, sehingga tidak ada alasan lagi bagi sekolah untuk mengelak dari upaya tersebut (Muhaimin, 2009).

Salah satu faktor yang berperan penting dalam pengembangan budaya agama di sekolah adalah peran aktif komunitas madrasah yaitu kepala madrasah, guru, karyawan, dan siswa. Akan tetapi sebagai pimpinan, kepala madrasah mempunyai andil dan peran terbesar karena di tangan kepala madrasah, kebijakan kebijakan tersebut dibuat dan dilaksanakan oleh segenap warga sekolah.

Urgensi pengembangan budaya agama di madrasah adalah agar seluruh warga sekolah memperoleh kesempatan untuk dapat memiliki bahkan mewujudkan seluruh aspek keberagamaannya baik pada aspek keyakinan (keimanan), praktik agama, pengalaman, pengetahuan agama, dan dimensi pengamalan keagamaan. Semua itu dapat diwujudkan melalui berbagai kegiatan keagamaan sebagai wahana dalam upaya menciptakan dan mengembangkan budaya religius di madrasah.

Di Palembang ada beberapa sekolah yang memiliki model pembinaan keberagamaan siswa seperti SMA Negeri 16 Palembang dengan komunitas sekolah dan Rohis (Suryana \& Maryamah, 2013); MA Negeri 3 Palembang dengan boarding school (M. 3 Palembang, 2015); SMA Plus Negeri 17 Palembang dengan sistem asrama (S. P. N. 17 Palembang, 2015); dan SMA Negeri 6 Palembang dengan unggulan lokal berbasis IMTAQ (Martalinda, 2011). Masingmasing sekolah tersebut memiliki keunggulan/kekhasan tersendiri dalam rangka membina soft skill/karakter para peserta didik yang sesuai dengan tujuan pendidikan.

Fenemona ini berkembang saat ini didasari oleh adanya kesadaran pihak sekolah tentang pentingnya pembelajaran agama di sekolah dan dukungan dari para orang tua siswa yang khawatir anaknya terjerumus pada perilaku-perilaku yang menyimpang dari nilai-nilai agama, keluarga, dan masyarakat seperti narkoba, seks bebas, aborsi, minuman keras, dan sebagainya. Hal inilah yang mendasari berkembangnya model/strategi pembinaan keberagamaan di berbagai sekolah. Model tersebut efektif dalam menghalangi para siswa untuk melakukan perbuatan menyimpang.

Pembinaan keberagamaan siswa melalui berbagai model di atas memiliki efek/dampak secara tidak langsung/sampingan. Walaupun tidak secara langsung, dampak tersebut penting dalam rangka membentuk karakter/akhlak siswa seperti tanggung jawab, disiplin, jujur, dan sebagainya.

Dampak/efek yang dirasakan secara tidak langsung tersebut dinamakan hidden curriculum. Menurut Jane Martin, hidden curriculum sebagai sesuatu yang melekat dalam struktur sosial, otoritas pengalaman guru, dan berbagai kebijakan dan aturan yang mengatur hubungan kepala sekolah, para pendidik, tenaga kependidikan, para staf, dan murid di dalam sekolah (Hidayat, 2011). Sedangkan Dakir, hidden curriculum adalah kurikulum yang tidak direncanakan, tidak 
diprogram dan tidak dirancang tetapi mempunyai pengaruh, baik secara langsung maupun tidak langsung terhadap output dari proses belajar mengajar (Noor, 2012). Hidden curriculum terdapat pada saat mengelola kelas, menguasai materi, dan sikap guru dalam menangani peserta didik yang melakukan kenakalan baik di kelas maupun di luar kelas. Dari sinilah maka terbentuk pengalaman-pengalaman yang akan mempengaruhi cara berpikir dan berperilaku siswa.

Penelitian tentang implementasi hidden curriculum melalui kegiatan keagamaan belum banyak diteliti. Ada beberapa penelitian yang telah dilakukan yang fokus pada pembinaan akhlak melalui tahfiz Qur'an (A. Fajar, 2012), Pembinaan Keberagamaan Siswa melalui Pengembangan Budaya Agama (Suryana \& Maryamah, 2013), Pengembangan Model Pembelajaran PAI Melalui Pembinaan Keagamaan Berbasis (Kosasih \& Fahrudin, 2009), Strategi Pembinaan Keagamaan Siswa (Shodiq, 2012), evaluasi pelaksanaan Program Iman dan Taqwa (IMTAQ) (Rindawan, 2014), pembinaan keagamaan (Latifah et al., 2015), dan lainnya. Oleh karenanya penelitian ini bertujuan untuk meneliti bagaimana implementasi hidden curriculum melalui ekstrakurikuler keagamaan di Madrasah Aliyah Patra Mandiri Palembang.

\section{Metode}

Penelitian ini merupakan penelitian kualitatif dengan pendekatan deskritif analitis, maka dalam pengumpulan data menggunakan teknik observasi, wawancara mendalam, dokumentasi dan analisis datanya menggunakan analisis data model Milles dan Huberman, yaitu melalui proses reduksi, display dan verifikasi.

\section{Hasil dan Pembahasan}

\section{Program Ekstrakurikuler Keagamaan}

\section{Salaman Pagi}

Salaman pagi adalah kegiatan menyalami dengan mencium tangan guru. Kegiatan ini dilaksanakan di halaman depan madrasah. Saat siswa memasuki gerbang atau lokasi madrasah, para guru (guru piket) berdiri dan berbaris panjang. Selanjutnya siswa satu persatu berbaris menyalami para guru. Bagi siswa yang telah menyalami guru diperbolehkan masuk ke madrasah melalui gerbang samping untuk bersiap-siap mengikuti kegiatan Ekstrakurikuler Keagamaan.

Kegiatan Salaman Pagi di MA Patra Mandiri identik dengan pendidikan yang ada di pesantren pada umumnya. Tapi tidak seintens yang ada di pesantren, setiap kali bertemu dengan guru/kiai mereka bersalaman/mencium tangan guru. Dari kegiatan ini, siswa dibiasakan hidup disiplin, menghormati guru, dan memperat tali silaturahim antara guru dan siswa.

\section{Salat Zuhur Berjemaah}

Salat Zuhur Berjemaah merupakan kegiatan yang rutin dari hari Senin hingga Sabtu. Kegiatan ini dilaksanakan pada jam istirahat kedua yaitu pada pukul 11.30 - 12.30 WIB. Seluruh siswa diwajibkan menjalan salatZuhur Berjemaah namun tidak wajib bagi siswa yang haid.

Sebelum salat Zuhur Berjemaah, guru bekerjasama dengan OSIS untuk menggiring siswa untuk mengambil air wudu. Setelah dinyatakan siap, salat Zuhur dilaksanakan. Untuk azan dan iqomah ditugaskan kepada siswa. Sedangkan imam dari guru.

Pelaksanaan Salat Zuhur sebagai bagian dari program Ekstrakurikuler Keagamaan merupakan bentuk tanggung jawab daripada pihak madrasah 
dalam membiasakan peserta didik untuk salat lima waktu yang telah diwajibkan kepada seluruh umat Muslim.

\section{Salat Duha}

Kegiatan salat Duha merupakan bagian dari program Ekstrakurikuler Keagamaan yang bersifat dianjurkan bagi seluruh siswa di MA Patra Mandiri. Kegiatan ini diperuntungkan bagi siswa dan dewan guru yang ingin medapatkan keutamaan dari salat Duha. Salat Dhuda dilaksanakan pada jam istirahat pertama yaitu pukul $9.30-10.00 \mathrm{WIB}$.

Sebelum melakukan salat Duha, pihak Madrasah mengumumkan melalui alat pengeras suara "waktunya salat Duha". Siswa dan dewan guru dipersilakan mengambil air wudu. Kemudian pelaksanaan salat Duha dimulai. Salat Duha dilaksanakan Berjemaah atau munfarid (sendirisendiri). Peserta didik diberikan kebebasan untuk melaksanakan salat Duha dengan 2, 4, hingga 8 raka'at.

Salat Duha yang dilaksanakan di MA Patra Mandiri Palembang sebagai salah satu upaya pihak madrasah dalam membiasakan salat sunah bagi peserta didik. Salat Duha yang dilaksanakan secara berjemaah dan sendiri-sendiri.

\section{Salat Jumat Berjemaah bagi Laki-laki}

Salat Jumat Berjemaah dilaksanakan pada setiap hari Jumat. Kegiatan ini dikhususkan bagi siswa laki-laki. Jama'ah salat Jumat terdiri atas siswa laki-laki, dewan guru, dan masyarakat sekitar. Pelaksanaan Salat Jumat bagi siswa lakilaki di MA Patra Mandiri Palembang merupakan bentuk menjalankan perintah Allah Swt.

\section{Tahsinul Qur'an}

Program Tahsinul Qur'an adalah program membaca al-Qur'an dengan baik dan benar yang dibimbing langsung oleh pembina program.
Kegiatan Tahsinul Qur'an dilaksanakan pada hari Selasa pada pukul $6.45-07.15$ WIB. Pembina kegiatan ini adalah Bapak Saidina Usman.

Ayat-ayat yang dibacakan pada Tahsinul Qur'an mencapai 5-7 ayat pada setiap pertemuannya. Ayat yang dibaca pada hari tersebut merupakan kelanjutan dari ayat pada pertemuan sebelumnya. Pada akhir pertemuan, pembina menyampaikan beberapa penjelasan mengenai makna dari ayat yang dibacakan jika waktu masih tersedia. Seluruh siswa dipersilakan masuk kelas masing-masing.

Program Tahsinul Qur'an merupakan kegiatan membaca al-Qur'an dengan baik dan benar yang dibimbing oleh pendidik/pembina yang memiliki kompetensi di bidangnya. Dalam kegiatan ini, peserta didik diajarkan cara membaca al-Qur'an sesuai dengan kaidah ilmu tajwid. Selain daripada itu, peserta didik juga dibekali dengan penjelasan kandungan dari ayat tersebut.

Untuk memahami dan mengimplementasi ajaran-ajaran yang bersumber dari al-Qur'an tentunya dimulai dengan membaca. Dengan membaca, diharapkan timbul rasa kecintaan peserta didik terhadap al-Qur'an dan timbul kesadaran untuk menerapkan ajarannya dalam kehidupan sehari-hari.

Melalui Tahsinul Qur'an, keberagamaan siswa dibina dengan membaca al-Qur'an yang menjadi sumber seluruh aspek kehidupan umat manusia. Dengan al-Qur'an, dapat menata kehidupan peserta didik yang lebih baik dan terarah. Karena al-Qur'an sumber ajaran kebaikan.

\section{Marhaba}

Program Marhaba merupakan kegiatan pembacaan syair-syair untuk mengetahui sejarah Rasulullah Saw. Kegiatan ini dilaksakan pada pagi hari para hari Rabu pukul 06.45 - 07.15 WIB. 
Adapun pendidik dalam kegiatan ini adalah Bapak Abdul Kadir.

Kegiatan ini sebelum dilaksanakan ada beberapa hal yang dipersiapkan yaitu 1) pembagian tugas kepada kelas oleh OSIS; 2) kelas yang mendapatkan tugas menunjuk teman-temannya untuk menjadi petugas melalui mekanisme musyawarah; 3) persiapan tempat; dan 4) para petugas melakukan pra-kegiatan dengan pembina kegiatan agar pelaksanaan acara berjalan sesuai dengan harapan.

Pada hari pelaksanaan, seluruh siswa dipersilakan masuk ke Masjid yang dipandu oleh dewan guru, pembina, dan OSIS. Bagi kelas yang menjadi petugas dipersilakan untuk maju ke depan. Kemudian pembina membuka acara dan mempersilakan petugas untuk membaca Marhaba. Para petugas dalam membaca Marhaba menggunakan pengeras suara dan irama lagu.

\section{Barzanji}

Program Barzanji merupakan pembacaan Kitab Barzanji yang dikarang oleh Syekh Ja'far bin Hasan. Yang membedakan dengan program Marhaba adalah irama lagu, Barzanji tanpa irama lagu. Pembina program ini adalah Bapak Drs. Kasmuyadi.

Kegiatan ini sebelum dilaksanakan ada beberapa hal yang dipersiapkan yaitu 1) pembagian tugas kepada kelas oleh OSIS; 2) kelas yang mendapatkan tugas menunjuk teman-temannya untuk menjadi petugas melalui mekanisme musyawarah; 3) persiapan tempat; dan 4) para petugas melakukan pra-kegiatan dengan pembina kegiatan agar pelaksanaan acara berjalan sesuai dengan harapan.

\section{Muhadhoroh}

Muhadhoroh merupakan sebuah kegiatan berbicara di depan umum atau berorasi untuk menyatakan pendapatnya, atau memberikan gambaran tentang suatu hal. Kegiatan ini dilaksanakan pada hari Jumat pukul 06.45 - 07.30 WIB.

Kegiatan ini sebelum dilaksanakan ada beberapa hal yang dipersiapkan yaitu 1) pembagian tugas kepada kelas oleh OSIS; 2) kelas yang mendapatkan tugas menunjuk teman-temannya untuk menjadi petugas melalui mekanisme musyawarah meliputi a) MC, b) Pembaca Ayat Suci al-Qur'an, c) Penceramah, dan d) Pembaca doa; 3) persiapan tempat; dan 4) para petugas melakukan pra-kegiatan dengan pembina kegiatan agar pelaksanaan acara berjalan sesuai dengan harapan.

\section{Impelementasi Hidden Curriculum dalam Ekstrakurikuler Keagamaan}

Mengutip artikel dari Dyah Kumalasari, Benson Snyder, para pendidik, sosiolog, dan psikolog dalam melukiskan sistem informal dalam dunia pendidikan. Hidden curriculum disebutkan terdiri atas tiga $\mathrm{R}$ yang sangat penting untuk dikembangkan yaitu rules (aturan), regulation (peraturan), dan routines (kontinu). Di mana setiap sekolah yang menerapkan sistem ini harus beradaptasi. Sosialisasi nilai-nilai moral merupakan suplemen dari tiga $\mathrm{R}$, pelajaran atau mata kuliah tersebut juga akan menjadi jelas dan mudah dipahami bila disampaikan dengan jalan klasikal dalam ruang kelas yang teratur (Balantine, 1983).

Setiap bentuk hidden curriculum tersebut memiliki pengaruh tersendiri dalam memberikan pengalaman belajar siswa. Tentunya pengaruh yang diciptakan disini diharapkan memberikan efek positif bagi siswa. Infrastruktur yang disediakan diharapkan mampu memfasilitasi siswa. Sikap dan cara berpakaian guru yang sopan dan baik diharapkan dapat menjadi contoh dan tauladan bagi siswa. Dan pembiasaan-pembiasaan di madrasah 
diharapkan dapat melahirkan budaya baru yang baik, sehingga pembiasaan tersebut tertanam kedalam kepribadian setiap siswa.

Kegiatan ekstrakurikuler keagamaan di MA Patra Mandiri dalam mengimplementasikan hidden curriculum melalui tiga cara yaitu 1) kegiatan rutin; 2) kegiatan mingguan; dan 3) keteladanan guru. Untuk lebih rincinya dapat diuraikan sebagai berikut:

\section{Kegiatan Rutin}

1. Doa bersama. Kegiatan doa bersama-sama dilakukan setiap memulai semua aktivitas ekstrakurikuler keagamaan. Doa bersama biasanya dipandu oleh MC dalam sebuah kegiatan dan pembina. Doa bersama dilakukan sebelum dan sesudah melakukan kegiatan dengan mengucapkan Bismillah dan atau Surat al-Fatihah di awal dan diakhiri dengan Hamdalah dan atau Surat al-Fatihah.

Pendidikan karakter yang ditanamkan melalui kegiatan ini adalah setiap perbuatan yang baik dengan niat yang baik haruslah diawali dengan yang baik pula. Selanjutnya nilai kebersamaan tersebut menjadi sumber kekuatan.

2. Salat Zuhur Berjamaah. Kegiatan ini dilakukan oleh guru dan siswa. Pelaksanaannya merupakan kewajiban yang harus dilakukan pada waktunya tiba. Yang menjadi imam biasanya perwakilan dari dewan guru. Setelah melakukan salat Zuhur, dilanjutkan kembali dengan aktivitas pembelajaran.

Pendidikan karakter yang ditanamkan melalui kegiatan ini adalah kedisiplinan waktu dan tanggung jawab sebagai Muslim yaitu menjalankan salat lima waktu di antaranya Salat Zuhur.

3. Salat Duha. Sholah Duha dilakukan oleh para guru dan siswa. Namun pelaksanaannya bukan merupakan kewajiban yang harus dilakukan oleh para siswa. Pada saat bel istirahat pertama berbunyi, sebagian siswa menuju ke Musholla untuk melakukan salat Duha tanpa ada paksaan.

Pendidikan karakter yang ditanamkan melalui kegiatan ini adalah rezeki tidaklah datang secara tiba-tiba melainkan perlu disertai dengan usaha dan doa. Melalui keutamaan salat Duha, insyaAllah rezeki datang dengan mudah.

4. Salaman Pagi. Kegiatan ini dilaksanakan pada pagi hari di halaman madrasah yang spesifiknya berada di depan gerbang. Satu hingga lima guru berdiri di halaman madrasah untuk menyambut kedatangan siswa dengan bersalaman. Salaman pagi juga digunakan untuk mendisiplinkan siswa mengenai waktu masuk madrasah. Bagi siswa yang terlambat akan mendapatkan hukuman yang mendidik seperti mengambil sampah di halaman; membersihkan halaman madrasah dan ruang dewan guru; dan menyiram tanaman. Aktivitas ini efektif dalam mendisiplinkan siswa.

Pendidikan karakter yang ditanamkan melalui kegiatan ini adalah menghormati guru; disiplin waktu; menjaga lingkungan; dan hidup bersih dan rapi.

5. Silaturahmi siswa dengan guru. Kegiatan ini dilakukan pada saat pagi hari dimana para siswa menemui semua guru dengan bersalaman. Aktivitas ini masih dilakukan secara mandiri tetapi sudah menjadi kebiasaan para siswa di pagi hari.

Pendidikan karakter yang ditanamkan dalam kegiatan ini adalah menghormati guru dan menjaga tali persaudaraan dengan guru. 


\section{Kegiatan Mingguan}

1. Tahsinul Qur'an. Kegiatan ini rutin dilaksanakan pada hari Selasa dengan Bapak Saidina Usman sebagai pembina kegiatan. Siswa diajarkan membaca al-Qur'an ayat per ayat dengan dibaca terlebih dahulu oleh pembina kemudian diikuti oleh para siswa. Materi yang diajarkan seputar tajwid dan kandungan ayat.

Pendidikan karakter yang ditanamkan melalui kegiatan ini adalah cinta al-Qur'an; menjadikan al-Qur'an sebagai tuntunan/pedoman; dan membaca al-Qur'an ada ilmunya.

2. Marhaba. Kegiatan ini rutin dilaksanakan pada hari Rabu dengan Bapak Abdul Kadir sebagai pembina kegiatan. Siswa membaca Marhabah yang telah dibagi perkelas oleh koordinator acara yaitu pengurus OSIS. Setiap kelompok/kelas membaca Marhaba secara bersama-sama.

Pendidikan karakter yang ditanamkan dalam kegiatan ini adalah mencintai Rasulullah Saw melalui sejarah perjalanan hidupnya dan sholawat.

3. Barzanji. Kegiatan ini rutin dilaksanakan pada hari Kamis dengan Bapak Kasmuyadi sebagai pembinanya. Siswa membaca Barzanji dengan irama lagu yang diajarkan oleh pembinanya. Dari kegiatan ini, siswa dapat diharapkan dapat mencintai Rasulullah Saw. hingga menjadikan Beliau sebagai suri teladan.

4. Muhadhoroh. Kegiatan ini dilaksanakan pada hari Jumat pagi dengan Bapak Kasmuyadi sebagai pembinanya. Ada banyak siswa yang terlibat dalam kegiatan ini seperti MC, pembaca ayat al-Qur'an, ceramah agama, penampilan lainnya, dan pembaca doa.
Pendidikan karakter yang ditanamkan dalam kegiatan ini adalah cara berbicara//komunikatif, berani, percaya diri, dan hidup bermasyarakat.

5. Salat Jumat. Kegiatan ini dilaksanakan khusus bagi siswa pada hari Jumat di masjid-masjid sekitar madrasah. Dewan guru dan siswa secara bersama-sama melaksanakan salat Jumat.

Pendidikan karakter yang ditanamkan melalui kegiatan ini adalah tanggung jawab sebagai Muslim dengan kewajibannya melaksanakan salat Jumat. Selain daripada itu, mereka juga ditanamkan karakter religius.

\section{Keteladanan Guru}

1. Kedisplinan. Disiplin adalah tindakan yang menunjukkan perilaku patuh dan taat kepada tata tertib dan peraturan yang ada. Guru selalu datang lebih awal ke sekolah, sebelum bel masuk berbunyi. Datang tepat waktu merupakan contoh perilaku disiplin terhadap waktu. Perilaku seperti ini merupakan bentuk dari hidden curriculum. Secara tidak langsung pembelajaran tentang disiplin telah diajarkan kepada siswa dimana guru memberikan contoh nyata atau langsung yakni dengan datang lebih awal agar tidak terlambat.

2. Silaturahmi Dewan Guru. Silaturahmi merupakan kegiatan menjalin persaudaran sesama guru. Sesama guru berjabatan tangan ketika bertemu di lingkungan madrasah. Berjabatan tangan tersebut dilakukan baik di ruang guru maupun ketika bertemu. Praktek yang dilakukan guru ini sebagai bentuk hidden curriculum kepada siswa tentang menjaga tali persaudaraan.

3. Berpakaian rapi dan sopan. Pakaian rapi dan 
sopan yang dikenakan oleh guru pada setiap kegiatan ekstrakurikuler keagamaan secara tidak langsung memberikan contoh kepada siswa yakni siswa ketika di madrasah atau di luar sebaiknya memakai pakaian yang rapi dan sopan.

4. Hidup Bersih. Praktek hidup bersih ini dipraktekkan oleh guru saat memberikan hukuman kepada siswa yang terlambat dalam bentuk mengambil sampah di halaman; membersihkan halaman madrasah dan ruang dewan guru. Salah satu bentuk hidup bersih adalah menjaga lingkungan sekitar dari kotoran/sampah.

\section{Kesimpulan}

Implementasi hidden curriculum dalam ekstrakurikuler keagamaan melalui tiga cara yaitu a) kegiatan rutin yaitu doa bersama, sholat zuhur berjamaah, sholat Dhuha, salaman pagi, dan silaturahmi siswa dengan guru; b) kegiatan mingguan yaitu Tahsinul Qur'an, Marhaba, Barzanji. Muhadhoroh, dan sholat Jumat; dan c) keteladanan guru yaitu kedisplinan, silaturahmi dewan guru, berpakaian rapi dan sopan, dan hidup bersih.

\section{Daftar Pustaka}

Balantine, J. H. (1983). The Sociology of Education a Systematic Analysis. Intence Hall Inc.

BNN. (2016). Hasil Survei Penyalahgunaan dan Peredaran Gelap Narkoba pada Kelompok Pelajar dan Mahasiswa di 18 Provinsi Tahun 2016. Badan Narkotika Nasional. http://www.bnn.go.id/_multimedia/document /20170227/ringkasan_eksekutif_rev_cetak_1 8_feb.pdf

Fajar, A. (2012). Pembinaan Akhlak melalui Tahfidh Al-Qur'an: Studi Deskriptif Analitis di PesantrenPersatuan Islam Karangpawitan Tingkat Tsanawiyah Garut. Universitas Pendidikan Indonesia.
Fajar, A. M. (2005). Holistika Pemikiran Pendidikan. Raja Grafindo Persada.

Hidayat, R. (2011). Pengantar Sosiologi Kurikulum. Rajawali Pers.

Kosasih, A., \& Fahrudin, S. A. (2009). Pengembangan Model Pembelajaran PAI Melalui Pembinaan Keaagamaan Berbasis Tutorial Menuju Terciptanya Kampus UPI Religius. Jurnal Penelitian Vol, 9(1).

Latifah, Y., Fakhruddin, A., \& Suresman, E. (2015). Pembinaan Keagamaan Siswa Smp Di Pondok Pesantren Daarut Tauhiid Bandung. TARBAWY: Indonesian Journal of Islamic Education, 2(2), 137-150.

Martalinda, E. (2011). Meningkatkan Prestasi dan Prestise SMA Negeri 6 Palembang Unggulan Berbasis Imtak Melalui Pemberdayaan Kegiatan Ekstrakurikuler Rohis.

Muhaimin. (2009). Rekonstruksi Pendidikan Islam: dari Paradigma Pengembangan, Manajemen Kelembagaan, Kurikulum hingga Strategi Pembelajaran. Raja Grafindo Persada.

Noor, R. M. (2012). The Hidden Curriculum (Membangun Karakter Melalui Kegiatan Ekstrakurikuler). Insan Madani.

Palembang, M. 3. (2015). Program Asrama MAN 3 Palembang. MAN 3 Palembang.

Palembang, S. P. N. 17. (2015). SMA Plus Negeri 17 Palembang.

Penyusun, T. (2003). Undang-undang Republik Indonesia nomor 20 tahun 2003 tentang sistem pendidikan nasional. Pemerintah Republik Indonesia.

Rindawan, S. (2014). Evaluasi pelaksanaan program iman dan taqwa SMPN di kecamatan Gerung. Jurnal Evaluasi PendidikanVolume, 2(1).

Shodiq, S. (2012). Strategi Pembinaan Aktivitas Keagamaan Siswa di Sekolah Dasar Negeri Tlogoarum 01 dan Sekolah Dasar Negeri Trangkilan Kecamatan Wedari Jaksa Kabupaten Pati. IAIN Walisongo.

Suryana, E., \& Maryamah, M. (2013). Pembinaan keberagamaan Siswa Melalui Pengembangan Budaya Agama di SMA Negeri 16 Palembang. Ta'dib: Jurnal Pendidikan Islam, 18(02), 169-214. 